Arab World English Journal (AWEJ) $2^{\text {nd }}$ Special Issue on Covid 19 Challenges January 2022 DOI: https://dx.doi.org/10.24093/awej/covid2.9.

\title{
Investigating Saudi Female Students' Familiarity of Word-Formation Processes Related to COVID-19 Pandemic Terminology
}

\author{
Salma Musleh Alqahtani \\ Faculty of Languages and Translation \\ King Khalid University, Saudi Arabia \\ Email:smosleh@kku.edu.sa
}

Received:11/512021

Accepted:12/8/2021

Published: $1 / / 24 / 2022$

\begin{abstract}
With the outbreak of the COVID-19 pandemic, new words appeared in English. EFL learners need to learn the new words. Learners depend on many strategies to help them learn new terms. Investigating this topic is significant because it will contribute to the knowledge of teaching and learning new words that appeared rapidly and suddenly. This study aims to investigate the acquisition of word-formation processes related to COVID-19 terms. The research seeks to answer two questions: (1) Are Saudi female EFL learners familiar with English word-formation processes? (2) Do word-formation processes aid Saudi female EFL students in learning COVID19 pandemic terms? The study used a quantitative method. The data was collected from 71 Saudi female students via a multiple-choice electronic questionnaire. The results revealed that the percentages of incorrect responses were higher than the percentages of correct ones, thus suggesting that the students were not familiar with word-formation processes. The findings showed that they had similar results in words formed via compounding and blending, indicating they failed to distinguish between the two processes. The findings show that the Saudi female students did not prefer to use a word-formation process over the other. Further, results showed that even though some of the common COVID-19 terms frequently were used on a daily basis, the students failed to predict and use the correct word-formation processes for those terms. The findings as a whole reveal that Saudi learners had difficulty in learning word-formation processes deriving COVID-19 terms. The study proposes some recommendations for further research.
\end{abstract}

Keywords: COVID-19 pandemic terminology, EFL learners, Saudi female students' familiarity, vocabulary learning, word-formation process

Cite as: Alqahtani, S. M. (2022). Investigating Saudi Female Students' Familiarity of Word-

Formation Processes Related to COVID-19 Pandemic Terminology. Arab World English Journal (AWEJ) $2^{\text {nd }}$ Special Issue on Covid 19 Challenges (2) 135-154.

DOI: https://dx.doi.org/10.24093/awej/covid2.9 
Arab World English Journal (AWEJ) 2nd Special Issue on Covid 19 Challenges January 2022

Investigating Saudi Female Students' Familiarity of Word-Formation Processes

Alqahtani

\section{Introduction}

Coronavirus respiration disease has become a worldwide pandemic, as the World Health Organization (WHO) stated in March 2020. The WHO's website reported approximately 195,266,156 confirmed cases of coronavirus; 4,180,161 confirmed deaths; and 3,829,935,772 vaccine doses administered as of July 28, 2021. This pandemic has affected the lives of millions around the world. Language is definitely one aspect that has undergone rapid changes during this tough period. As a result, new words have been created and emerged quickly as the number of confirmed cases of this disease has increased.

The term "coronavirus" consists of two words: corona, which means "crown," and virus (Al-Salman \& Haider, 2021; Asif, Zhiyong, Iram, \& Nisar, 2021; Thorne, 2020). In January 2020, the WHO started to call this type of coronavirus COVID-19 (i.e., coronavirus disease 2019). Thus, lexicographers started to document in dictionaries new related words. Additionally, medical centers, such as the Texas Medical Center (Becker, 2020, cited in Al-Salman \& Haider, 2021), Yale Medicine (Katella, 2020), and the Saudi Ministry of Health (2021), collected lists on their websites of COVID-19-related terms to familiarize people with the new terms. As for dictionaries, in March 2020, Merriam-Webster (2021) added new words related to COVID-19, such as COVID-19, social distancing, super-spreader, and index case. Also, the lexicographers of the Oxford English Dictionary (2021) updated the dictionary with words, such as contacttracer, comorbid, face covering, $R$ number, field hospital, spike protein, and shelter in place.

The new words related to COVID-19 were created by word-formation processes (AlSalman \& Haider, 2021; Asif et al., 2021; Goltsova \& Chybis, 2021). A word-formation process is a tool used to create new words out of existing words (Bauer, 1983, 2004; Nordquist, 2020; Yule, 2020). Word-formation processes include various devices, such as blending, clipping, compounding, conversion, backformation, affixation, abbreviation, borrowing, acronyms, and reduplication (Akmadjian, Demers, Farmer, \& Harnish, 2017; Bauer, 2004; Brinton \& Brinton, 2010; O'Grady, Archibald, Arronof, \& Rees-Miller, 2017). For instance, the word coronavirus is created from two words, "corona" and "virus" via compounding. Compounding is a morphological process that uses two free roots to create a new word (Yule, 2020). This massive explosion of new terms in a short period of time requires a deep insight into how learners will cope with learning these new words and the word-formation processes responsible for creating new vocabularies.

Vocabulary is a fundamental element in language teaching and learning (Richards \& Rodgers, 2001). The COVID-19 epidemic has prompted the creation of new words in English related to this disease, which English as a foreign language (EFL) learners might struggle to learn (Nation \& Waring, 1997). With the outbreak of the COVID-19 pandemic, hundreds of new words appeared rapidly in English and other languages. From this, EFL students need to improve their acquisition of these new terms. Learners can rely on various strategies to help them acquire new terms. Schmitt (1997), for instance, claimed there were many strategies to increase learners' knowledge of words, such as "strategies for the discovery of a new word's meaning" and strategies intended for "consolidating a word once it has been encountered" (p. 207). Nation and Waring (1997) mentioned that learners could rely on word parts to learn and remember new words. The learners could predict the new words' meaning according to the context in which the words appear. Word-formation processes can also increase learners' knowledge of new terms. 
Arab World English Journal (AWEJ) 2nd Special Issue on Covid 19 Challenges January 2022

Investigating Saudi Female Students' Familiarity of Word-Formation Processes

Alqahtani

Eventually, EFL learners must gain command of word-formation processes because this skill is fundamental in word recognition (Soudek, 1981). Thus, this paper aims to investigate Saudi female EFL students' learning of word-formation processes related to COVID-19 pandemic terms.

Based on the literature, little is known about how Saudi female EFL students learn wordformation processes. To the best of the author's knowledge, Al-Jarf (2011) is the only one who has investigated teaching word-formation processes to Saudi translation students. Al-Jarf's (2011) study provided a description of word-formation devices taught to translation students at King Saud University. The results showed that the students had difficulty comprehending wordformation processes, resulting in students' failure to translate technical terms. Unlike the previous studies, this paper presents a study of Saudi female EFL learners' familiarity of wordformation processes related to COVID-19 pandemic terms. Specifically, it is based on the extent to which comprehending word-formation processes can help Saudi female EFL learners understand new terms related to COVID-19. This study strives to answer two questions:

1. Are Saudi female EFL learners familiar with English word-formation processes?

2. Do word-formation processes aid Saudi female EFL students in learning COVID-19 pandemic terms?

\section{Review of Related Literature}

In this section, the researcher first provides a brief description of the word-formation processes involved in constructing terms related to COVID-19 in English. The other section is devoted to previous literature related to the current study, which is conducted on the acquisition, learning, and teaching of word-formation processes.

\section{Studies on Word-Formation Processes Related to COVID-19}

English has many word-formation devices for constructing new words from existing ones, such as compounding, blending, clipping, acronyms, abbreviation, conversion, affixation, back-formation, and borrowing (Bauer, 1983; Yule, 2020). There is a relatively small body of literature concerned with providing a linguistic analysis of word-formation processes involved in constructing new terms related to COVID-19 (Al-Salman \& Haider, 2021; Asif et al., 2021; Fitria, 2021; Goltsova \& Chybis, 2021). Akut (2020) and Asif et al. (2021) found that most neologisms related to COVID-19 are nouns. Akut (2020) claimed that only three common wordformation devices were involved in constructing words related to COVID-19: compounding, blending, and affixation. Asif et al. (2021) found that acronyms and abbreviations were very common with English neologisms related to COVID-19. In a recent study, Fitria (2021) reported that types of word-formation processes involved in forming COVID-19 terms included borrowing (e.g., rapid test), compounding (e.g., coronaspeck), blending (e.g., infodemic), acronyms (e.g., WFO from "work from office"), clipping (e.g., Iso), and multiple processes (e.g., coronababies).

In the same vein, Al-Salman and Haider (2021) offered an in-depth analysis of the processes used for creating English neologisms related to COVID-19. They reported that there were two types of word-formation processes: single word-formation and double word-formation processes. The single process includes processes such as "coinages, affixation, compounding, blending, clipping, backformation, borrowing, abbreviation, acronyms, and folk-etymology" (Al- 
Salman \& Haider, 2021, p. 30). The double process, on the other hand, includes "compounding and affixation, blending and affixation, and clipping and compounding" (p. 32). They further stated that the term "COVID-19" is an example of coinage, a single process that can be perceived as the invention and creation of totally new words, either unintentionally or intentionally (Yule, 2020). Affixation is the process of attaching bound morphemes to free morphemes to create new words, such as "masklessness, which means "wearing no face-covering [sic]"” (Al-Salman \& Haider, 2021, p. 31). The word "sedate" was created from the adjective "sedative" via backformation, which is a process that removes the affix from the original word. Al-Salman and Haider (2021) said that the word "unlockdown," which means "the process of relaxing or ending social and physical restrictions, or the period following their ending, equivalent to, or [the] translation of the French deconfinement" (p. 32) is an example of borrowing. BCV (the period before Corona [virus]) and WFH (working from home) are examples of abbreviations, which are shortened versions of words after extracting the initial letters of each word in the phrase to create new words. Al-Salman and Haider (2021) defined folk etymology as the meaning of a word or its form being altered as a result of "a mistaken assumption about its composition or meaning" (p. 32), for example, the word "nightingales" being used as a label for people who sing or perform on balconies. The word is used now to refer to "[n]ightingale emergency hospitals...[that] opened across the UK" (Al-Salman \& Haider, 2021, p. 32).

As for the double word-formation processes, Al-Salman and Haider (2021) mentioned that the word "circuit-breakers" is created by two devices - compounding "circuit-break" and adding two suffixes to the compound: the suffix "-er" to make a noun and the suffix "-s" to pluralize the noun. They provided another example of blending and affixation with the word "quaranteams," which is constructed by "quarantine" and "team" and adding a plural suffix marker to the blended form. Al-Salman and Haider (2021) defined clipping and compounding as the process of shortening one form and then combining it with another form. For example, the novel word "ronadobbing" is created from "corona" and "dobbing" to become "coronadobbing," then the word corona is shortened to "rona," which forms the word "ronadobbing." They concluded that most COVID-19 terms were not novel and existed before the outbreak; the pandemic has caused such words to reappear and to be used on a daily basis.

Collectively, these studies provided important insights into the various word-formation processes used to construct COVID-19 terms. Previous studies have only focused on terms that appeared on websites, newspapers, and social media and did not addressed how learners or those who did not work in the health field understood the new terms or how they were constructed. Thus, this paper fills this gap in literature and studies if learners know what type of wordformation devices are used to create the new terms appearing during this pandemic.

\section{Studies on Word-Formation Processes}

This section is divided into two subsections: The first subsection deals with the acquisition of word-formation processes and the second subsection is devoted to the learning and teaching of the word-formation processes.

\section{Acquiring Word-Formation Processes}

There is a lack of literature regarding the acquisition of word-formation processes for learners of a second language (L2) or foreign language (FL; Al-Jarf, 2011; Broeder, Exira, van 
Arab World English Journal (AWEJ) 2nd Special Issue on Covid 19 Challenges January 2022

Hout, \& Voionmaa, 1993; Olshtain, 1987; Redouane, 2003; Tschichold \& ten Hacken, 2015) compared to the first language (L1) acquisition of word-formation devices (Clark, 1981, 1998; Dressler, 2003; Lahaa \& Dressler, 2012; Schipke \& Kauschke, 2011). Many factors are accounted for in L1 acquisition of word-formation processes, such as formal simplicity, regularity, conventionality, predictability, productivity, and semantic and morphological transparency (Clark, 1998; Dressler, 2003; Lahaa \& Dressler, 2012). In a major study, LilloMartin (1984) examined the L1 acquisition of word-formation processes in deaf children. The participants were 24 deaf children learning American Sign Language as their L1 and 16 deaf adults. The children's ages ranged from three to 10 years old. This study focused on wordformation devices that were also found in spoken language, such as affixation, compounding, and derivation. The author used two tests. The first test required the participants to give a name for "something giv[ing] a verbal description of its function" (Lillo-Martin, 1984, p. 74), and the second test required participants to name invented items given in pictures. Lillo-Martin (1984) studied the effect of the principles of acquiring word formation, such as semantic transparency, formal simplicity, productivity, and conventionality. The results showed that younger children did not use compounding, whereas the older children used it more often. Adults used compounding more frequently than both younger and older children. The youngest children also used derivation more than the older children and adults. Interestingly, formal simplicity and semantic transparency had vital roles in acquiring these devices. Affixation and compounding were regarded as transparent, and derivation was formally simple.

L1 and sign language acquisition studies have provided detailed information about the role of word-formation devices and their forms in the mental lexicon; however, it is unclear how L2 acquisition provides information about word-formation processes in the mental lexicon (Tschichold \& ten Hacken, 2015). The following paragraphs summarize some of the findings and conclusions regarding the acquisition of word-formation processes.

Broeder et al. (1993) used a longitudinal study to investigate the use of word-formation processes in Dutch, English, and Swedish languages by 12 native speakers of six languages: Arabic, Punjabi, Turkish, Italian, Finnish, and Spanish. This study focused on exploring informants' use of innovative words related to concepts, such as kinship, instruments, and places. The findings revealed that L2 learners of English, Dutch, and Swedish preferred compounding to derivation when creating new words; they hardly used derivation in their production. This was attributed to how semantic transparency played a major role in their preferences of wordformation processes.

Olshtain (1987) examined the acquisition of word-formation devices in Hebrew as an L2 learner. The participants were both adult L2 learners of Hebrew and native Hebrew speakers, and L2 learners had different L1 backgrounds (i.e., English and Spanish). Three written questionnaires were used to collect data: a production task questionnaire, an evaluation task questionnaire, and an interpretation task questionnaire. The native Hebrew speakers and two groups of L2 (advanced and intermediate) learners received the three questionnaires. In the first questionnaire, the participants were asked to come up with innovations for words that were not found in the existing lexicon. The second questionnaire asked the participants to choose the most suitable innovation for words. The last one asked the participants to interpret innovative blends. The results revealed that advanced L2 learners had similar behaviors in choosing word-formation 
processes as native Hebrew speakers. This indicated that L2 learners grasped the word-formation processes of the Hebrew language to reach competence, implying that advanced L2 learners were able to create innovations in Hebrew similar to native speakers. However, intermediate L2 learners lacked competence in the L2. Thus, acquiring word-formation strategies is a gradual process. Interestingly, advanced L2 learners used compounding more frequently than derivation, whereas intermediate L2 learners opted to use affixation more extensively than compounding. Olshtain (1987) attributed this finding to how intermediate L2 learners were familiar with and exposed to the affixation, having received direct instruction from their teachers and practiced using affixation in their Hebrew courses.

In a similar study, Redouane (2003) studied the acquisition of word-formation processes by L2 adult learners of Modern Standard Arabic (MSA) and how they used these devices in creating novel words. The participants were 44 L2 learners of MSA (whose L1s were English and French) and 40 native MSA speakers. Three tasks were administered to the participants to collect data, including a production task and two comprehension tasks. The findings of the three tasks revealed that L2 learners opted to use compounding more frequently than derivation, while native speakers preferred to use derivation (i.e., affixation and germination) more than the other word-formation processes.

Recently, Madsen (2019) investigated English L2 learners' preferences for wordformation devices when they were required to create new words from provided keywords. He also studied whether the word-formation processes in the participants' native languages affected their preferences of word-formation devices in English. The participants were Danish, Israeli, and Slovene students whose L2 was English. The results showed that the participants' mother tongues did not affect the differences between the three groups. Another interesting finding showed that the participants preferred to use derivation and compounding more than inflection when creating new words. In sum, the L2 learners seemed to prefer compounding as a process that aided them in understanding and using the new or novel words. This proves that acquiring word formation processes indeed helps learners to learn new words.

\section{Studies on Teaching and Learning Word-Formation Processes}

The focus on teaching the internal structure of words and how words are created rather than describing language in communicative approaches has attracted researchers' attention (AlJarf, 2011; Balteiro, 2011; Clark \& Berman, 1984; Laufer, 1997; Nation, 2000; Ur, 1996; Zimmerman, 1997). Zimmerman (1997) claimed that the lexicon was crucial in L2 acquisition, yet the vocabulary's internal construction and teaching had not received major attention in the field of L2 acquisition. The focus in L2 acquisition studies has mostly been on the order of morpheme acquisition - more specific, whether L2 adult learners acquired and comprehended inflectional morphemes before or after derivational morphemes, recognized the morphemes, and used them productively (Derwing, 1976; Derwing \& Baker, 1977, 1979; Freyd \& Baron, 1982, cited in Lowie, 1998). These studies confirmed that the "comprehension of derivational affixes is acquired before the ability to use these affixes productively" (Lowie, 1998, p.106).

Balteiro (2011) reported that word-formation devices were naturally and easily acquired at an early age. However, L2 learners acquired the devices in a different way than natives did because of the "'artificial" nature of the teaching and/or learning environment" and of the "(natural or expected) quantitative difference in exposure to the language" (Balteiro, 2011, p. 
Arab World English Journal (AWEJ) 2nd Special Issue on Covid 19 Challenges January 2022

26). Her paper focused on how word-formation processes could help L2 learners increase their vocabulary sources, consequently leading them to be autonomous learners. L2 learners have a limited a number of vocabulary resources; therefore, they must acquire word-formation processes. Teaching and learning word-formation processes is very important because learning these processes allow L2 learners to create new words, expand their lexicon and vocabulary, and convert the lexical items they may face or aid them in converting the ideas into lexical words even if they have not heard the words before (Balteiro, 2011). Ur (1996) and Nattinger (1988) believed that teaching L2 students how to distinguish the different forms of words and identify the most frequent affixes that form these words enabled them to create new words (as cited in Balteiro, 2011). This knowledge confirms the learners' competence and comprehension in L2 acquisition. Additionally, ten Hacken, Abel, and Knapp (2006) maintained that L2 learners should have a mental lexicon that contained a foundation allowing them to acquire additional words (as cited in Balteiro, 2011). This foundation should include knowledge of word-formation processes. Therefore, learning word-formation devices will aid learners' autonomy and independence to "develop their own lexicon in a more natural way, which does not require great memory efforts" (Balteiro, 2011, p. 28). Hankamer (1989) reported that "a typical educated speaker of Turkish, with a lexicon of approximately 20,000 noun roots and 10,000 verb roots, could dispose of more than 200 billion words based on this lexicon" (p. 28, as cited in Balteiro, 2011). Accordingly, word-formation devices aid L2 adult learners to be autonomous learners. Thus, L2 teaching and learning of the internal structure of words can help students learn, acquire, and memorize vocabulary, as well as infer and predict the meaning of new words. Al-Jarf (2011) studied the Saudi translation students' comprehension of word-formation processes in the Arabic and English languages. The participants were 20 junior Saudi females. In a need-assessment questionnaire, she found that the students had no comprehension of word-formation processes in English, such as "compounding, derivation, back formation, conversion, extension, blending, clipping, acronyms and abbreviations, onomatopoeia, borrowings and neologisms" (Al-Jarf, 2011, p. 160). Consequently, the students had difficulty translating technical items from English into Arabic. Al-Jarf (2011) then implemented a direct instruction of word-formation processes for 8 weeks, and the results of the posttest revealed this method was useful in increasing students' comprehension of word-formation processes in both the Arabic and English languages. Similarly, Mahraj (2018) studied whether word-formation processes could aid Moroccan students to identify and learn technical words related to computer engineering. The majority of students were not familiar with word-formation processes before direct instruction. Khoury (2008) obtained similar results through a study that examined whether the root-and-pattern method might assist learners to encode, produce, and identify new words in L2 acquisition of Arabic; L2 learners who were taught word-formation processes directly outperformed those who did not receive direct instruction on word-formation processes.

The language-learning process involves learning and acquiring a great deal of vocabulary. Thus, vocabulary learning is fundamental in the field of communicative competence (Canale \& Swain, 1980). Learning vocabulary meaning or definition is more critical than grammar to understand any text (Barcroft, 2004) because knowing the meaning increases one's vocabulary depth. Vocabulary depth, as Nation (2000) assumed, involves recognizing the words' various characteristics that involve the words' morphological features and properties. He argued that word formation was vital in vocabulary learning and enhanced learners' meaning retention. Balteiro (2011) and Tahaineh (2012) believed that word-formation processes did not entail 
explicit instruction because learners comprehended and inferred these processes as they progressed in language learning and became autonomous learners as a result.

With the coronavirus pandemic, schools and universities have been closed worldwide, and students have stayed home. Online classes have been provided as a substitute for face-toface instruction. Students are exposed to new terminologies related to COVID-19 via TV, social networks, and classes on a daily basis. Thus, students are obliged to use and comprehend these new words. Therefore, Suparsa and Mantra (2020) investigated the extent to which students had acquired COVID-19-related words. They required the students to mention, define, and explain 60 new words related to COVID-19 that they encountered on a daily basis. Students did not adequately understand terms related to the COVID-19 pandemic, although they were exposed to the words daily. The researchers attributed this failure to several factors, such as the students' low overall academic achievements. Some students were unable to form clear and correct sentences to explain the terms, and some failed to express the terms in their own words. Additionally, the majority of students favored searching the Internet for the definitions and explanations of COVID-19 terms. Suparsa and Mantra (2020) concluded that the students had difficulty comprehending COVID-19 terms because those words were "related to medical sciences" (p. 41), and thus the students were not exposed to them.

To conclude, the language learners must comprehend both the devices that form words and a lexicon of words. Thus, the learners' familiarity and knowledge of word-formation processes "goes hand-in-hand with learning the specific make-up of the vocabulary" in any language (Clark \& Berman, 1984, p. 543). The word-formation learning implies learning how to analyze various forms and uses of words. It also aids learners to recognize the relationship between meaning and form, and how to identify the various uses of lexical words or items.

\section{Methodology}

To achieve the main aim of this study, the researcher used a quantitative approach to collect data and to analyze it.

\section{Participants}

A convenience sample was used in this study. The sample included 71 Saudi female EFL students in the English Department at the Faculty of Languages and Translation, King Khalid University. The students were in Levels seven and eight (fourth year in the English program) in the English Department. The participants' ages ranged from 19 to 21 years old. The participants had participated in EFL education for almost nine years (three years in intermediate school, three years in high school, and three years in college). The participants had finished two years in the English Department, where they were extensively taught four skills: reading, writing, speaking, and listening. They were also taught two courses in vocabulary building and four courses in grammar. After they finished the first two years, they started to study other English courses, such as morphology, syntax, introduction to linguistics, applied linguistics, literature, and translation. The researcher chose these two levels (seven and eight) because the participants had completed all of the basics related to vocabulary learning, grammar, and language skills. There were no official test results to show the participants' level in English; however, they had completed and passed the courses in the department. Thus, the researcher considered the participants' levels to 
be advanced because they were in their last year (fourth year) in the English Department. The students participated in this study in the summer semester of 2021.

\section{Research Instruments}

The study employed a quantitative approach to collect the data. The researcher collected the data via a multiple-choice electronic questionnaire that Google Forms administrated. The questionnaire consisted of two sections: The first section was designed to collect data about the participants' ages and grade level; the second section was designed to collect data about wordformation processes. This second section consisted of 20 statements written in English to elicit students' correct choices of the word-formation processes (see Appendix A). The researcher developed the questionnaire statements to test participants' comprehension of four wordformation processes: compounding, blending, clipping, and acronym. The researcher chose these processes specifically to elicit data because they are the most common word-formation devices used to create COVID-19 terms based on the literature reviewed above (Al-Salman \& Haider, 2021). The researcher provided the definition of word-formation processes in the questionnaire to ensure the students understood this term. The questionnaire's 20 statements were divided as follows: six statements were developed to test students' comprehension of compounding, six were developed for blending, four were used for acronyms, and four were used for clipping. Each statement included a COVID-19 term. Four choices were provided for each statement to ensure the students' choices were accurate: compounding, blending, clipping, and acronym. A sample of these statements is shown in (1). This example aimed to elicit data for the blending process, and the answer to this process is (b).

(1) The term "quaranteen" is created from "quarantine" and "teen" by
a. Compounding
b. Blending
c. Clipping
d. Acronym

To test the questionnaire's reliability, two assistant professors of linguistics reviewed and confirmed its content.

\section{Procedure}

The participants were informed about the main goal of this research. They participated voluntarily in the study. The questionnaire was sent to the participants as a Google form. The students were asked to choose the correct answer that represented the correct word-formation process involved in creating COVID-19 terms. The participants required around $30 \mathrm{~min}$ to complete the questionnaire.

\section{Data Analysis}

The researcher carried out a quantitative data analysis to examine participants' acquisition of word-formation processes, and the researcher marked the participants' responses. The students were required to choose only one response. The questionnaire was checked for correct and incorrect responses. The correct responses were marked as 1 and the incorrect responses as 0 . The correct responses of each process were calculated and converted into percentages. The means of Saudi female students' responses to the questionnaire statements and the graphs were calculated using Microsoft Excel (version 16) and SPSS (version 26). 


\section{Results}

The author classified the results into two sections. The first section presented with the results of Saudi female EFL students' familiarity, choices, and use of the correct word-formation processes. The second section presented the results of learning compounding, blending, clipping, and acronym words related to COVID-19 terms and if these processes aid Saudi learners to comprehend COVID-19 terms.

\section{Familiarity of Word-Formation Processes}

The author performed descriptive statistics to obtain the results of Saudi female EFL learners' familiarity, choices, and use of the correct word-formation processes for COVID-19 terms. Table one presents the results of four word-formation processes deriving COVID-19 terms. The correct responses are analyzed in the table. Six COVID-19 words were chosen in the test for creating COVID-19 terms through compounding. Likewise, six words for creating COVID-19 terms through blending, four words for creating COVID-19 terms through clipping, and four words for creating COVID-19 terms through acronyms were selected to test whether the Saudi female students were familiar with using and understanding the word-formation processes.

Table 1. Descriptive statistics for correct responses of word-formation processes

\begin{tabular}{llcccc}
\hline Variable & $\begin{array}{c}\text { Compoundi } \\
\text { ng } \\
(N=6)\end{array}$ & $\begin{array}{c}\text { Blending } \\
(N=6)\end{array}$ & $\begin{array}{c}\text { Clipping } \\
(N=4)\end{array}$ & $\begin{array}{c}\text { Acronym } \\
(N=4)\end{array}$ \\
\hline $\begin{array}{l}\text { Word- } \\
\text { formation } \\
\text { processes } \\
(N \text { of } \\
\text { students }\end{array}$ & Mean & 25.33 & 25.33 & 22.75 & 31.25 \\
\cline { 2 - 6 } 71$)$ & Percent & 35 & 35 & 32 & 44 \\
\cline { 2 - 6 } & Std. & 2.804 & 5.428 & 6.652 & 6.751 \\
\hline
\end{tabular}

The study's results reveal that Saudi female EFL learners are not familiar with the wordformation processes used to create COVID-19 terms in general. As shown in Table one, there are no differences between the mean score and percent of compounding (35\%) and blending (35\%) processes. Saudi students' correct responses in terms of clipping are 32\%, which is very low. Clipping is considered the most problematic word-formation process for students to comprehend. However, the participants' correct responses regarding the acronym process (44\%) are more than the other three word-formation processes.

Figure one below presents the overall results of students' correct and incorrect responses in percentages. The figure shows that most participants did not correctly answer the statements in the questionnaire. The largest number of incorrect responses $(68 \%)$ was found in the clipping process. This finding reveals that the majority of Saudi female learners are not aware of wordformation processes. 
Arab World English Journal (AWEJ) 2nd Special Issue on Covid 19 Challenges January 2022

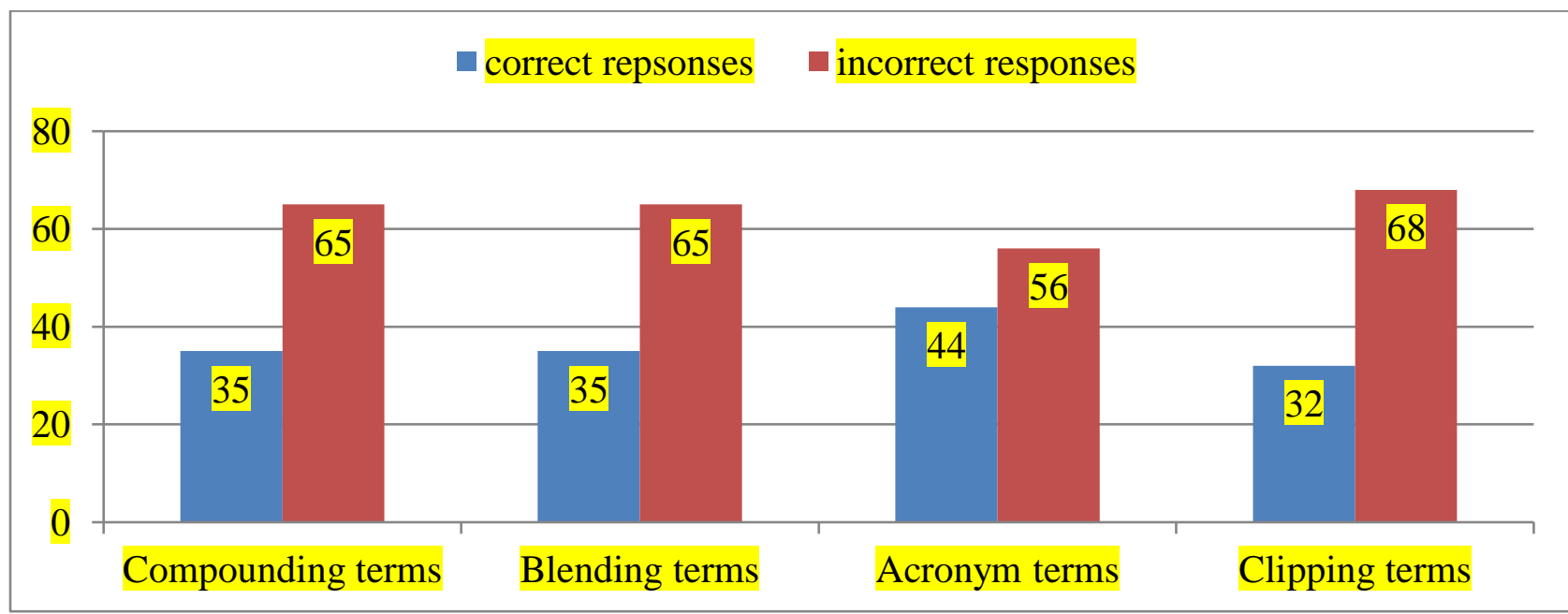

Figure 1. Percent of participants' correct and incorrect responses regarding word-formation processes

\section{Word Formation Processes Aid in Learning COVID-19 Terms Compounding}

The results shown in Table two reveal the students' performance in the compounding process across six terms. The mean and percent of correct responses across six COVID-19 terms are very low. This suggests that Saudi female learners had difficulty in learning COVID-19 terms that the compounding process formed. Surprisingly, the percent of choosing the correct word-formation process (i.e., compounding for the term coronavirus) is very low (38\%), even though this term is used widely on a daily basis and repeatedly in the media. This also indicates that the students had significant difficulty in learning the compounding process. Almost the same result was found with the term "hand sanitizer," which is currently considered a common word. Only 25 out of $71(35 \%)$ students were able to use the compounding process for this term. Thus, the students had problems in learning about and comprehending the compounding process. This failure leads the students to have difficulty in learning and comprehending the new terms related to COVID-19.

Table 2. Descriptive statistics for students' correct responses in the compounding process

\begin{tabular}{lcccc}
\hline Compounding terms & Mean & $\begin{array}{l}\text { Mean raw sore of } \\
\text { correct responses }\end{array}$ & Percent & Std. Deviation \\
\hline $\begin{array}{l}\text { Term 1 } \\
\text { (Hand sanitizer) }\end{array}$ & .35 & 25 & 35 & .481 \\
\hline $\begin{array}{l}\text { Term 2 } \\
\text { (Lockdown) }\end{array}$ & .39 & 28 & 39.4 & .492 \\
\hline $\begin{array}{l}\text { Term 3 } \\
\text { Corona coma) }\end{array}$ & .31 & 22 & 31 & .466 \\
\hline $\begin{array}{l}\text { Term 4 } \\
\text { (Self-quarantine) }\end{array}$ & .31 & 22 & 31 & .466 \\
\hline $\begin{array}{l}\text { Term 5 } \\
\text { Corona viva) }\end{array}$ & .39 & 28 & 39.4 & .492 \\
\hline $\begin{array}{l}\text { Term 6 } \\
\text { Coronavirus) }\end{array}$ & .38 & 27 & 38 & .489 \\
\hline
\end{tabular}


Arab World English Journal (AWEJ) 2nd Special Issue on Covid 19 Challenges January 2022

\section{Blending}

Table three displays results for the blending process deriving COVID-19 terms. The students' correct uses of this process were analyzed. Six terms were selected to test students' comprehension of blending.

Table 3. Descriptive statistics for students' correct responses in the blending process

\begin{tabular}{lcccc}
\hline Compounding terms & Mean & $\begin{array}{l}\text { Mean raw sore of } \\
\text { correct responses }\end{array}$ & Percent & Std. Deviation \\
\hline $\begin{array}{l}\text { Term 1 } \\
\text { Quaranteen) }\end{array}$ & .42 & 30 & 42 & .497 \\
\hline $\begin{array}{l}\text { Term 2 } \\
\text { (Infodemic) }\end{array}$ & .32 & 23 & 32 & .471 \\
\hline $\begin{array}{l}\text { Term 3 } \\
\text { (Covidiot) }\end{array}$ & .31 & 22 & 31 & .466 \\
$\begin{array}{l}\text { Term 4 } \\
\text { (Staycation) }\end{array}$ & .32 & 23 & 32 & .471 \\
$\begin{array}{l}\text { Term 5 } \\
\text { (Telemedicine) }\end{array}$ & .48 & 34 & 48 & .503 \\
\hline $\begin{array}{l}\text { Term 6 } \\
\text { (loxit) }\end{array}$ & .28 & 20 & 28 & .453 \\
\hline
\end{tabular}

The results in this table reveal that the word "loxit," which is formed by blending "lockdown" and "exit," is the most problematic word for students. Only $28 \%$ of students were able to understand how this word was created via the blending process. The Saudi female students had less difficulty in learning the process of forming "telemedicine" and "quaranteen" ( $48 \%$ and $42 \%$, respectively). As for the other three terms (terms two, three, and four), the students had difficulty learning them. The percentages of correct responses are less than the incorrect ones, which suggests the students had difficulty learning the process that forms these words (i.e., blending). This process did not help the students comprehend the new words. Further, the table shows that the students have difficulty in comprehending terms related to COVID-19.

\section{Clipping}

Table four shows the students' correct responses across four terms. As the table exhibits, the students had the most difficulty learning COVID-19 terms formed via clipping. Only the term "sanny" shows that $45 \%$ of students had less difficulty in predicting the process that formed this term. However, this percentage is still very low compared to the other terms across the four word-formation processes.

Table 4. Descriptive statistics for students' correct responses in the clipping process

\begin{tabular}{lcccc}
\hline Compounding terms & Mean & $\begin{array}{l}\text { Mean raw sore of } \\
\text { correct responses }\end{array}$ & Percent & Std. Deviation \\
\hline $\begin{array}{l}\text { Term } 1 \\
\text { (iso) }\end{array}$ & .27 & 19 & 27 & .446 \\
\hline $\begin{array}{l}\text { Term 2 } \\
\text { (sanny) }\end{array}$ & .45 & 32 & 45 & .501 \\
\hline $\begin{array}{l}\text { Term 3 } \\
\text { (pandy) }\end{array}$ & .32 & 23 & 32 & .471 \\
\hline $\begin{array}{l}\text { Term 4 } \\
\text { (rona) }\end{array}$ & .24 & 17 & 24 & .430 \\
\hline
\end{tabular}


The term "rona," which is shortened from "corona," has the lowest percent of correct responses (17\%). This suggests that the students had difficulty in learning the clipping process even though they were told how the word was created. The same result is also found with the word "iso," which is clipped from "isolation." Again, the students were unaware of this process, which results in their failure to learn and understand COVID-19 terms.

\section{Acronym}

Table five indicates that the students had difficulty in learning the acronym process, especially with the term "COVID-19," which had $35 \%$ of the correct responses. Even though it is common, most of the students had difficulty in learning the process that formed this term. However, the students had higher percentages with the other three terms, as shown in Table five below. This indicates the students might depend on the term's form to predict which wordformation process is responsible for that term. In this case, all three terms (WFH, BCV, and ACV) are very short, unlike the term COVID-19. However, the percentages of correct responses in this process (i.e., acronym) are higher than the other three processes.

Table 5. Descriptive statistics for students' correct responses in the acronym process

\begin{tabular}{lcccc}
\hline Compounding terms & Mean & $\begin{array}{l}\text { Mean raw sore of } \\
\text { correct responses }\end{array}$ & Percent & Std. Deviation \\
\hline $\begin{array}{l}\text { Term 1 } \\
\text { (WFH) }\end{array}$ & .56 & 40 & 56 & .499 \\
\hline $\begin{array}{l}\text { Term 2 } \\
\text { (COVID-19) }\end{array}$ & .35 & 25 & 35 & .481 \\
\hline $\begin{array}{l}\text { Term 3 } \\
(\text { BCV) }\end{array}$ & .46 & 33 & 46 & .502 \\
\hline $\begin{array}{l}\text { Term 4 } \\
(\text { ACV })\end{array}$ & .38 & 27 & 38 & .489 \\
\hline
\end{tabular}

\section{Discussion}

This study aimed to examine if Saudi female EFL students are aware of and familiar with word-formation processes, if these processes aid the students in learning words related to COVID-19, and to examine if students comprehend COVID-19 terms. The overall findings show that the percentages of incorrect responses are higher than the percentages of correct responses. This indicates that Saudi female learners did not learn the word-formation processes and thus are not familiar with them, even though they were advanced students in Levels seven and eight. This unfamiliarity indicates the Saudi female EFL learners had difficulty in learning word-formation processes. This result goes in line with Al-Jarf's (2011) and Mahraj's (2018) research, which also found that Saudi and Moroccan students, respectively, did not acquire the word-formation processes. When they provided a direct instruction to their students, their scores improved as a result. The findings of this study reveal that the students' responses were different for all of the word-formation processes, suggesting the students might have learned some of the processes before the others, as in the case of the acronym process, which the students performed well in. However, they had not completely learned that process. The learning process is thus considered in this case a gradual learning. These results are consistent with Al-Jarf's (2011) and Olshtain's (1987) results which also found that the learners acquired the word-formation processes gradually. 
The results also show that even though some of the common COVID-19 terms were frequently used in their conversations (e.g., COVID-19, hand sanitizer, and coronavirus), they still failed to predict and use the correct word-formation processes for those common terms. These results go along with those obtained by Suparsa and Mantra (2020), who found that the students lacked sufficient understanding of terms related to the COVID-19 pandemic, even when exposed to the words on a daily basis. This result might be attributed to the L1 transfer. The Saudi female students might rely on the translation of hand sanitizer, which is not a compound word in Arabic (i.e., their L1). The word mut $^{\S}$ ahir/muSaqim (sanitizer) or the phrase mut ${ }^{\S}$ ahir alyad (hand sanitizer) is a simple word, not a compound word. Mostly, speakers in their conversations use the simple word mut $t^{\varsigma}$ ahir or muSaqim in reference to hand sanitizer in Arabic. Further, the word corona is sometimes not coined with the word virus in Arabic speech; for example, an individual might say "ana ausibt bi Korona" (I am infected with the corona) instead of "Pana Pus ibt bi firu:s Kuruna" (I am infected with the coronavirus). Both statements are used correctly in Arabic speech. This might affect the results in the word-formation processes. Another reason for the students' failure to comprehend these processes could be related to the COVID-19 terms, which are considered difficult because they are related to the medical field (Suparsa \& Mantra, 2020). Clark and Berman (1984) and Nation (2000) explained that language learners must have competence in both words and word-formation devices so they can learn the new vocabulary they encounter in any language. Because Saudi female students had difficulty mastering the word-formation processes, they failed to understand COVID-19 terms, even though most of these terms are used daily. The word-formation processes did not aid the students in comprehending and learning the new words. The students were unable to analyze these terms because they lacked the tools to help them become autonomous learners, as Balteiro (2011) and Tahaineh (2012) claimed.

The findings show that the Saudi female students did not seem to prefer a word-formation process over the other, as Olshtain (1987), Broeder et al. (1993), Redouane (2003), Khoury (2008), and Madsen (2019) also showed. Even so, for the current study, this finding is quite surprising because the students are considered advanced learners of the English language. It also suggests that the Saudi female participants have not yet mastered the word-formation processes. In contrast, Redouane (2003) showed that the advanced L2 learners preferred to use compounding in creating novel words, and Madsen (2019) showed that the participants preferred to use two word-formation processes, derivation and compounding, in creating new words more than the other methods.

\section{Limitations and Recommendations}

This study has some limitations such as sample size. A larger sample might provide more reliable conclusions. Additionally, only four types of word-formation processes were tested in this paper. Other types, such as borrowing, backformation, and derivation, can be studied in further research to obtain reliable results and conclusions. The participants were females from Levels seven and eight; further research might be conducted to include male and female students from different levels to validate and generalize this study's results. The study used a quantitative instrument to collect data. Using a qualitative instrument in future research might enhance and provide valuable and generalized results. 


\section{Conclusion}

In this paper, the researcher was concerned with examining the Saudi female EFL learners' comprehension of the word-formation processes related to COVID-19 terms. These terms are derived by various word-formation devices, and in this paper, the author chose four word-formation processes because they were the most common in forming the COVID-19 terms, as based on the literature reviewed above. The percentages of incorrect responses were extremely higher than the percentages of correct ones, indicating the students had difficulty in learning these devices. The learners are still in the process of learning them, even though their academic level is advanced. The results show that the students also had the least number of correct responses in the clipping device, whereas they had better results in the acronym device. They had similar results in words formed via compounding and blending, suggesting they failed to distinguish between the two processes. The findings as a whole reveal that Saudi female learners had difficulty in learning word-formation processes deriving COVID-19 terms. This conclusion affirms that teaching word-formation processes explicitly for terms (e.g., technical and medical) is very important. Another cause for this result is that the students learn established and new words as a single element or item without being conscious of how they are combined, shortened, or derived from other words. The findings indicate that both the students and teachers should be aware of the importance of learning and teaching new vocabulary.

\section{About the Author}

Dr. Salma Musleh Alqahtani is an assistant professor of linguistics in the Department of English Language, Faculty of Languages and Translation, King Khalid University, Saudi Arabia. Her fields of interest are linguistics, applied linguistics, Saudi Arabic morphology and syntax, language learning and teaching, and First and Second language acquisition. ORCID: https://orcid.org/0000-0003-0055-8349

\section{References}

Akmadjian, A., Demers, R. A., Farmer, A. K., \& Harnish, R. M. (2017). Linguistics: An introduction to language and communication. MIT Press.

Akut, K. B. (2020). Morphological analysis of the neologisms during the COVID-19 pandemic. International Journal of English Language Studies, 2(3), 1-7.

Al-Jarf, R. (2011). Teaching English word-formation processes to translation students. Komunikacija I Kultura Online, 2(2), 160-174.

Al-Salman, S., \& Haider, A. H. (2021). COVID-19 trending neologisms and word formation processes in English. Russian Journal of Linguistics, 25(1), 24-42. doi:10.22363/2687 -0088-2021-25-1-24-42

Asif, M., Zhiyong, D., Iram, A., \& Nisar, M. (2021). Linguistic analysis of neologism related to coronavirus (COVID-19). Social Sciences \& Humanities Open, 4(1), 1-6. https://doi.org/10.1016/j.ssaho.2021.100201

Balteiro, I. (2011). Awareness of L1 and L2 word-formation mechanisms for the development of a more autonomous L2 learner. Porta Linguarum, 15, 25-34. doi: 10.30827/Digibug.31981

Barcroft, J. (2004). Second language vocabulary acquisition: A lexical input processing approach. Foreign Language Annals, 37(2), 200-208. https://doi.org/10.1111/j.19449720.2004.tb02193.x

Bauer, L. (1983). English word-formation. Cambridge University Press. 
Arab World English Journal (AWEJ) 2nd Special Issue on Covid 19 Challenges January 2022

Bauer, L. (2004). The function of word-formation and inflection-derivation distinction. In $\mathrm{H}$. Aersten, M. Hannay, \& R. Lyall (eds.), Words in their Places (pp. 283-292). Amsterdam: Vrije Universiteit.

Becker, A. (2020). COVID-19 crisis catalog: A glossary of terms. Texas Medical Center. https://www.tmc.edu/news/2020/05/covid-19-crisis-catalog-a-glossary-of-terms/

Broeder, P., Exira, G., van Hout, R., \& Voionmaa, K. (1993). Word formation processes in talking about entities. In C. Perdue (ed.), Adult language acquisition: Cross-linguistic perspective (pp. 41-72). Cambridge University Press.

Brinton, L. G., \& Brinton, D. M. (2010). The linguistic structure of modern English. John Benjamins Publishing.

Canale, M., \& Swain, M. (1980). Theoretical bases of communicative approaches to second language teaching and testing. Applied Linguistics, 1(1), 1-47. https://doi.org/10.1093/applin/I.1.1

Clark, E. (1981). Lexical innovations: How children learn to create new words. In W. Deutsch (ed.), The child's construction of language (pp.299-328). London: Academic Press.

Clark, E. (1998). Morphology in language acquisition. In A. Spencer, \& A. M. Zwicky (eds.), The handbook of morphology (pp. 374-389). Oxford \& Cambridge: Blackwell.

Clark, E. \& Berman, R. (1984). Structure and use in the acquisition of word formation. Language, 60(3), 542-590.

Derwing, B. L. (1976). Morpheme recognition and the learning of rules for derivational morphology. Canadian Journal of Linguistics, 21(1), 38-66. doi:10.1017/S0008413100008045

Derwing, B. L., \& Baker, W. J. (1977). The psychological basis for morphological rules. In J. MacNamara (Ed.), Language and thought (pp. 85-110). Academic Press.

Derwing, B. L., \& Baker, W. J. (1979). Recent research on the acquisition of English morphology. In P. Fletcher, \& M. Garman (eds.), Language acquisition: Studies in first language development (pp. 209-224). Cambridge University Press.

Dressler, W. U. (2003). Degrees of grammatical productivity in inflectional morphology. Rivista di Linguistica, 15(1), 31-62.

Fitria, T. N. (2021). Word formation process of terms in COVID-19 pandemic. Leksika: Jurnal Bahasa, Sastra dan Pengajarannya, 15(1), 18-26. doi: 10.30595/lks.v15i1.9248

Freyd, P., \& Baron, J. (1982). Individual differences in acquisition of derivational morphology. Journal of Verbal Learning and Verbal Behaviour, 21, 282-295.

Goltsova, M. G., \& Chybis, L. V. (2021). Coronavirus neologisms in the English and Ukrainian languages. International Journal of Philology, 12(1), 45-48. http://dx.doi.org/10.31548/philolog2021.01.045

Hankamer, J. (1989). Morphological parsing and the lexicon. In W. D. Marslen-Wilson (Ed.), Lexical representations and process (pp. 392-408). MIT Press.

Katella, K. (2020). Our new COVID-19 vocabulary-what does it all mean? Yale Medicine Organization. https://www.yalemedicine.org/news/covid-19-glossary

Khoury, G. (2008). Vocabulary acquisition in Arabic as a foreign language: The root and pattern strategy, (Unpublished Doctoral dissertation). Boston University, United States.

Laaha, S., \& Dressler, W. U. (2012). Suffix predictability and stem transparency in the acquisition of German noun plurals. In F. Kiefer, M. Ladányi, \& P. Siptár (eds.), Current issues in morphological theory: (Ir)regularity, analogy and frequency (pp. 217-236). John Benjamins Publishing. 
Arab World English Journal (AWEJ) 2nd Special Issue on Covid 19 Challenges January 2022

Laufer, B. (1997). What's in a word that makes it hard or easy: Some internal factors that affect the learning of words. In N. Schmitt, \& M. McCarthy (eds.), Vocabulary: Description acquisition and pedagogy (pp. 140-155). Cambridge: Cambridge University Press.

Lillo-Martin, D. (1984). The acquisition of task-specific word formation devices in American sign language. Papers and Reports on Child Language Development, 23, 74-81. https://eric.ed.gov/?id=ED249783

Lowie, W. (1998). The acquisition of interlanguage morphology: A study into the role of morphology in the L2 learner's mental lexicon [Doctoral dissertation, University of Groningen].

Madsen, R. S. (2019). Word-formation preferences of non-natives. SKASE Journal of Theoretical Linguistics, 16(1), 162-176. http://www.skase.sk/Volumes/JTL39/pdf_doc/12.pdf

Mahraj, M. (2018). Teaching technical vocabulary through word formation rules. International Arab Journal of English for Specific Purposes, 1, 37-44.

Merriam-Webster. (2021). Coronavirus and the new words we added to the dictionary in March 2020. Available at https://www.merriam-webster.com/words-atplay/new-dictionarywords-coronavirus-covid-19

Nation, I. S. P. (2000). Learning vocabulary in another language. Cambridge University Press.

Nation, P., \& Waring, R. (1997). Vocabulary size, text coverage, and word lists. In N. Schmitt, \& M. McCarthy (eds.), Vocabulary: Description, acquisition, and pedagogy (pp. 6-19). Cambridge University Press.

Nattinger, J. (1988). Some current trends in vocabulary teaching. In R. Carter \& M. McCarthy, (Eds.), Vocabulary and language teaching (pp. 62-82). Longman.

Nordquist, R. (2020). How Neologisms Keep English Alive. Retrieved from https://www.thoughtco.com/neologism-words-term-1691426

O'Grady, W., Archibald, J., Arronof, M., \& Rees-Miller, J. (2017). Contemporary linguistics: An introduction. Bedford/St. Martin's.

Olshtain, E. (1987). The acquisition of new word formation processes in second language acquisition. Studies in Second Language Acquisition, 9(2), 221-231. Retrieved June 21, 2021, from http://www.jstor.org/stable/44487408

Oxford English Dictionary. (2021). Updates to the OED. https://public.oed.com/updates/

Redouane, R. (2003). Learners' variability in coining new words in L2. Al-'Arabiyya, 36, 49-80. Retrieved June 21, 2021, from http://www.jstor.org/stable/43195709

Richards, J. C., \& Rodgers, T. S. (2001). Approaches and methods in language teaching ( $2^{\text {nd }}$ ed.). Cambridge University Press.

Schipke, C. S., \& Kauschke, C. (2011). Early word formation in German language acquisition: A study on word formation growth during the second and third years. First Language, 31(1), 67-82. https://doi.org/10.1177/0142723709359240

Schmitt, N. (1997). Vocabulary learning strategies. In N. Schmitt \& M. McCarthy (Eds.), Vocabulary: Description, acquisition, and pedagogy (pp. 199-227). Cambridge University Press.

Soudek, L. I. (1981). The lexicon and word formation in language teaching. Paper presented at the Joint Midwest TESOL Conference $\left(1^{\text {st }}\right)$ and the Illinois TESOL/BE Conference $\left(9^{\text {th }}\right)$, Champaign-Urbana, Illinois. 
Suparsa, I. N., \& Mantra, I. B. N. (2020). COVID-19 terminologies: The extent of student's vocabulary acquisition during learning from home. International Journal of Linguistics and Discourse Analytics, 2(1), 41-47.

Tahaineh, Y. (2012). The awareness of the English word-formation mechanisms is a necessity to make an autonomous L2 learner in EFL context. Journal of Language Teaching and Research, 3(6), 1106-1113. doi:10.4304/j1tr.3.6.1105-1113

ten Hacken, P., Abel, A., \& Knapp, J. (2006). Word formation in an electronic learners' dictionary: ELDIT. International Journal of Lexicography, 19(3), 243-256.

Thorne, T. (2020). Spotlight on COVID: Pandemic language and the role of linguistics. King's College London. News Centre. https://www.kcl.ac.uk/news/spotlight-on-covid-pandemic -language-and-the-role-of-linguists-1

Tschichold, C., \& ten Hacken, P. (2015). Word-formation in second language acquisition. Peter O. Müller, I. Ohnheiser, S. Olsen, \& F. Rainer (eds.), Word-formation: An international handbook of the language of Europe (pp. 2137-2154). Mouton de Gruyter.

Ur, P. (1996). A course in language teaching. Practice and theory. Cambridge University Press.

World Health Organization. (2021). WHO Coronavirus (COVID-19) Dashboard

Yule, G. (2020). The study of language. Cambridge University Press.

Zimmerman, C. (1997). Historical trends in second language vocabulary instruction. In J. Coady, \& T. Huckin (eds.), Second language vocabulary acquisition: A rationale for pedagogy (pp, 5-19). Cambridge, UK: Cambridge University Press.

\section{Appendices}

\section{Appendix A}

\section{Word-Formation Process of COVID-19 Terms}

Word-formation process is a tool that helps to create new words.

\section{Demographic Information}

\section{Part 1}

Age:

Level:

\section{Part 2}

Choose the word-formation process that formed the following terms:

\section{Compounding}

1. The term "hand sanitizer" is formed through
a. Compounding
b. Blending
c. Clipping
d. Acronym

2. The term "lockdown" is created from "lock" and "down" through
a. Compounding
b. Blending
c. Clipping
d. Acronym

3. The term "coronacoma" is created from "corona" and "coma" through

a. Compounding

b. Blending 
Arab World English Journal (AWEJ) 2nd Special Issue on Covid 19 Challenges January 2022
c. Clipping
d. Acronym

4. The term "self-quarantine" is created from "self" and "quarantine" through
a. Compounding
b. Blending
c. Clipping
d. Acronym

5. The term "coronaviva" is created from "corona" and "viva" through
a. Compounding
b. Blending
c. Clipping
d. Acronym

6. The term "coronavirus" is created from "corona" and "virus" through

\section{Blending}
a. Compounding
b. Blending
c. Clipping
d. Acronym

1. The term "quaranteen" is created from "quarantine" and "teen" by
a. Compounding
b. Blending
c. Clipping
d. Acronym

2. The term "infodemic" is created from "information" and "epidemic" by
a. Compounding
b. Blending
c. Clipping
d. Acronym

3. The term "covidiot" is created from "COVID-19" and "idiot" through
a. Compounding
b. Blending
c. Clipping
d. Acronym

4. The term "staycation" is created from "stay" and "vacation" through
a. Compounding
b. Blending
c. Clipping
d. Acronym

5. The term "telemedicine" is created from "telephone" and "medicine" by
a. Compounding
b. Blending
c. Clipping
d. Acronym

6. The term "loxit" is created from "lockdown" and "exit" through

Clipping
a. Compounding
b. Blending
c. Clipping
d. Acronym

1. The term "sanny" is created from "sanitizer" through 
Arab World English Journal (AWEJ) 2nd Special Issue on Covid 19 Challenges January 2022
a. Compounding
b. Blending
c. Clipping
d. Acronym

2. The term "pandy" is created from "pandemic" through
a. Compounding
b. Blending
c. Clipping
d. Acronym

3. The term "rona" is created from "corona" through
a. Compounding
b. Blending
c. Clipping
d. Acronym

4. The term "iso" is created from "isolation" through
a. Compounding
b. Blending
c. Clipping
d. Acronym

\section{Abbreviation and Acronym}

1. The term "COVID-19" is created from "coronavirus disease 2019" through
a. Compounding
b. Blending
c. Clipping
d. Acronym

2. The term "BCV," which refers to "(the period) before the corona(virus)," is created by
a. Compounding
b. Blending
c. Clipping
d. Acronym

3. The term "ACV," which refers to "(the period) after the corona(virus)," is created by
a. Compounding
b. Blending
c. Clipping
d. Acronym

4. The term "WFH" is created from "working from home" through
a. Compounding
b. Blending
c. Clipping
d. Acronym 